\title{
The growth performances and the gut health parameters of Sentul chickens supplemented with various dosage of turmeric powder
}

\author{
INDRAWATI Y. ASMARA ${ }^{1}$, TUTI WIDJASTUTI ${ }^{1}$, IWAN SETIAWAN ${ }^{1}$, ABUN $^{1}$, RUHYAT PARTASASMITA $^{2, \bullet}$ \\ ${ }^{1}$ Faculty of Animal Husbandry, Universitas Padjadjaran. Jl. Raya Bandung-Sumedang Km 21, Jatinangor, Sumedang 45363, West Java, Indonesia \\ ${ }^{2}$ Department of Biology, Faculty of Mathematics and Natural Sciences, Universitas Padjadjaran. Jl. Raya Bandung-Sumedang Km 21, Jatinangor, \\ Sumedang 45363, West Java, Indonesia. Tel. +62-22-7796412 ext. 104. Fax. +62-22-7794545, "email: ruhyat.partasasmita@unpad.ac.id; \\ rp2010rikkyo@gmail.com
}

Manuscript received: 22 May 2018. Revision accepted: 14 June 2018

\begin{abstract}
Asmara IY, Widjastuti T, Setiawan I, Abun, Partasasmita P. 2018. The growth performances and the gut health parameters of Sentul chickens supplemented with various dosage of turmeric powder. Nusantara Bioscience 10:121-125. The aim of this study was to investigate the effect of different levels of turmeric powder $(0,1,2,3 \mathrm{~g} / \mathrm{kg})$ on production performance and the number of Escherichia coli and Staphylococcus aureus bacteria in the intestine of Sentul chickens. The results showed that addition of $3 \mathrm{~g} / \mathrm{kg}$ of turmeric powder to diet significantly reduced feed intake (FI) and improved feed conversion ratio (FCR) of Sentul Chickens aged 9-16 weeks. The birds fed with control diet had the highest number of $S$. aureus and E. coli, while the birds fed with the diets added with 2 and 3 $\mathrm{g} / \mathrm{kg}$ turmeric powder had the lowest number of bacteria. The study reveals that increasing levels of turmeric powder in diets had positive effects on bird's performance and the number of intestinal bacteria. It can be concluded that a level of $3 \mathrm{~g} / \mathrm{kg}$ turmeric powder in diets gave the best result due to significantly improved FCR.
\end{abstract}

Keywords: Curcuma domestica, intestinal bacteria, performance, Sentul chickens, turmeric powder

\section{INTRODUCTION}

Indonesia is one of country, which the number of chicken domestication centers is largest in the world. The diversity of chickens in Indonesia is high and differ from other countries in Asia and in the world (Sulandari et al. 2008). It was reported that more than 30 distinct groups of local chickens are located in Indonesia (Nataamijaya 2000; Partasasmita et al. 2016). Some of them have specific plumage color and are regarded as an indigenous species i.e Sentul chickens (Diwyanto and Iskandar 1999),

Sentul Chicken is a local chicken from Ciamis region, West Java Province, Indonesia. Ciamis people also call Sentul chicken as 'Kulawu Chickens', kulawu means grey since the plumage colors of Sentul chickens are dominated by grey (Universitas Padjadjaran 2012). Sentul chickens had many advantages to be farmed because they are able to adapt to harsh environment and remain productive in low quality of diets (Widjastuti 1996). They produce 120-140 eggs per year (Universitas Padjadjaran 2012). The weight of adult male chickens can reach 1300-3500 g, whereas the weight of female adults is 800-2200 g (Sulandari et al. 2007). Nowadays, Sentul chickens are raised for meat industry. They are sold when their weights are about $750 \mathrm{~g}$ and the age of 2.5 months (Asmara 2014). However, like other local chickens such as Pelung and Kedu chickens, the population of Sentul chickens is declined and the status is in danger (Asmara 2014).

Sentul chickens are potential to be developed as organic poultry farms. One of characteristics of organic poultry farms is the use of natural feed additives and the prohibition of synthetic feed additives such as growth promoter antibiotics being used in chicken feeds. The natural feed additives derived from turmeric (Curcuma domestica $\mathrm{Val}$ ) have been used as one of alternatives of growth promoter antibiotics in poultry rations due to their safety for consumers. Turmeric is an essential component used in the Asian cuisines (Ganpati et al. 2011) as well as in Asian indigenous medicine as an antimicrobial agent (Lee et al. 2010; Moghadamtousi et al. 2014).

In animal farming, the use of turmeric and other herbs have positive effects on the feed intake, the secretion of digestive secretions and as anti-bacterial agents (Wenk 2003). Curcumin is identified as the main phytochemical in turmeric, which is responsible for biological effects (Teow et al. 2016). Tyagi et al. (2015) reported that curcumin, especially curcumin I is a significant component in commercial curcumin. It is effective against Gram-positive bacteria such as Staphylococcus aureus and Gram-negative bacteria such as Escherichia coli. Both bacteria are commonly found in gastrointestinal of mammals and birds. Some strains of E. coli may be pathogenic (Vidotto et al. 1990) and cause of negative impact in commercial poultry farms (Blanco et al. 1997), while S. aureus has ability to produce entero-toxins which may cause food poisoning in human (Mamza et al. 2010).

It has been reported that turmeric influences growth performances of poultry. Turmeric may possess an antibacterial effect in chickens (Samarasinghe et al. 2003; Lawhavinit et al. 2010; Akbarian et al. 2011; Ürüşan and Bölükbaş 2017), may depress abdominal fat (Samarasinghe et al. 2003), improve FCR in broilers (Ürüşan and 
Bölükbaş 2017), increase health status in local ducks (Nova and Yellita 2015) and increase egg production in local chickens (Widjastuti 2017). However, studies on turmeric powder in local chicken rations are rarely explored; thus, investigations of beneficial effects of turmeric powder in local chickens are required. The purpose of this study was to test effects of turmeric powder supplemented in local chicken diets from 0 to $3 \mathrm{~g} / \mathrm{kg}$ on the growth performances of chicken, i.e., feed intake (FI), weight gain (WG), feed conversion ratio (FCR) and intestinal bacteria of local chicken.

\section{MATERIALS AND METHODS}

\section{Experimental design}

This study was designed in Completely Randomized Design (CRD). A total of 100 day-old chicks (unsexed) of Grey Sentul Chickens was randomly distributed into 4 groups. The groups consisted of control and 3 treatment groups in which each group contained 5 sub-groups of five birds. In control group, the birds were fed with basal feed, while in treatment groups the birds were fed with the basal diet with different levels of turmeric powder $(1,2,3 \mathrm{~g} / \mathrm{kg}$, respectively). The feed and water were provided adlibitum. FI and WG were recorded weekly, while FCR was measured by dividing FI by WG.

The study was divided in two different phases and the diet compositions for each phase was shown in Table 1. The local ingredients used to produce the diets and the energy metabolism and protein needs were formulated based on Widjastuti (1996) diet formulation for Sentul chicken. At the end of the study, five birds were randomly selected from each treatment group and were slaughtered. A total of 20 carcasses were opened to collect samples of small intestine tracts of bird. All samples were proceeded at the same day for enumerating bacterial populations using methods reported by Safitri et al. (2008).

Table1. Feed ingredients and nutrient composition

\begin{tabular}{|c|c|c|}
\hline \multirow{2}{*}{ Feed ingredients } & \multicolumn{2}{|c|}{ Age } \\
\hline & 1-8 weeks & 9-16 weeks \\
\hline Yellow corn $(\%)$ & 56.00 & 58.00 \\
\hline Soybean meal (\%) & 12.00 & 4.75 \\
\hline Rice bran meal (\%) & 21.50 & 28.00 \\
\hline Fish meal (\%) & 9.25 & 8.00 \\
\hline $\mathrm{CaCo}_{3}(\%)$ & 0.50 & 0.50 \\
\hline Bone meal (\%) & 0.75 & 0.75 \\
\hline \multicolumn{3}{|l|}{ Nutrient composition: } \\
\hline Metabolism energy ( $\mathrm{kcal} / \mathrm{kg})$ & 2,850 & 2,755 \\
\hline Crude protein $(\%)$ & 17.00 & 15.08 \\
\hline Crude fat $(\%)$ & 5.92 & 6.66 \\
\hline Crude fiber $(\%)$ & 4.51 & 4.89 \\
\hline Calcium $(\%)$ & 1.16 & 1.05 \\
\hline Phosphorus (\%) & 0.63 & 0.58 \\
\hline Lysine $(\%)$ & 1.21 & 0.97 \\
\hline Methionine (\%) & 0.40 & 0.35 \\
\hline Methionine + lysine (\%) & 0.75 & 0.67 \\
\hline
\end{tabular}

\section{Data analyses}

Analysis of variance was applied to the data using statistical package program of SPSS version 19. Significantly different means were separated by a Duncan's multiple comparison test at 0.05 and 0.01 levels, respectively.

\section{RESULTS AND DISCUSSION}

Growth responses of local chickens on different dietary treatments were presented in Table 2. During week 1 until week 8 of study, dietary supplementation of 1,2 or $3 \mathrm{~g} / \mathrm{kg}$ had no significant effect on the growth parameters of birds, i.e., FI, WG, and FCR. the supplementation of turmeric in the diets significantly $(\mathrm{P}<0.05)$ changed the value of FI and FCR in week 9 until week 16, whereas the diets had no significant effect on WG.

FCR values were significantly influenced by dietary turmeric $(\mathrm{P}<0.05)$ during week 9 to week 16 (Table 2). FI values of the groups with supplemented by 2 and $3 \mathrm{~g} / \mathrm{kg}$ turmeric powder were significantly lower than those in 0 (control group) and $1 \mathrm{~g} / \mathrm{kg}$ turmeric powder, respectively. The lowest FCR was observed in the group with $3 \mathrm{~g} / \mathrm{kg}$ turmeric powder in diets, while the highest FCR was observed in the control group. It was found that the differences of FCR were significant between the groups $(\mathrm{P}<0.05)$. The best FCR occurred in the group with addition of $3 \mathrm{~g} / \mathrm{kg}$ turmeric powder in diet (5.19).

The highest dry matter digestibility occurred in the group supplemented with $3 \mathrm{~g} / \mathrm{kg}$ turmeric powder; while the lowest one was found in the group with the addition of $2 \mathrm{~g} / \mathrm{kg}$ turmeric powder (Table 3). It was observed that the highest crude protein digestibility occurred in the diets with the addition of $3 \mathrm{~g} / \mathrm{kg}$ turmeric powder.

Table 2. The effect of supplementation turmeric powder on performance of local chickens

\begin{tabular}{lrrrr}
\hline \multirow{2}{*}{ Variable } & \multicolumn{4}{c}{ Groups } \\
\cline { 2 - 5 } & Control & $\mathbf{1 ~ g / k g}$ & $\mathbf{2 ~ g / k g}$ & $\mathbf{3 ~ g} / \mathbf{k g}$ \\
\hline Aged 1-8 weeks & $1,802.60$ & $1,871.93$ & $1,757.93$ & $1,586.27$ \\
Feed intake (g) & 436.27 & 391.47 & 407.93 & 459.87 \\
Weight gain (g) & 4.21 & 4.86 & 4.31 & 3.59 \\
Feed conversion ratio & \multicolumn{4}{c}{} \\
Aged 9-16 weeks & $2,4012.39^{\mathrm{a}}$ & $23,698.12^{\mathrm{a}}$ & $22,250.04^{\mathrm{b}}$ & $21,429.36^{\mathrm{b}}$ \\
Feed intake (g) & 774.95 & 740.99 & 775.73 & 834.25 \\
Weight gain (g) & $6.23^{\mathrm{a}}$ & $6.41^{\mathrm{a}}$ & $5.74^{\mathrm{a}}$ & $5.19^{\mathrm{b}}$ \\
Feed conversion ratio & & &
\end{tabular}

Note: a, b, c, d: means within a row with no common superscript differ significantly $(p<0.05)$

Table 3. Nutrient digestibility of diets

\begin{tabular}{lcccc}
\hline \multirow{2}{*}{ Variable } & \multicolumn{4}{c}{ Groups } \\
\cline { 2 - 5 } & Control & $\mathbf{1 ~ g / k g}$ & $\mathbf{2} \mathbf{~ g} / \mathbf{k g}$ & $\mathbf{3} \mathbf{~ g} / \mathbf{k g}$ \\
\hline Dry matter (\%) & $59,86^{\mathrm{a}}$ & $55,75^{\mathrm{b}}$ & $53,86^{\mathrm{c}}$ & $66,05^{\mathrm{d}}$ \\
Crude protein (\%) & $75,67^{\mathrm{a}}$ & $72,79^{\mathrm{b}}$ & $75,78^{\mathrm{ac}}$ & $76,80^{\mathrm{c}}$ \\
\hline
\end{tabular}

Note: $a, b, c, d$ : means within a row with no common superscript differ significantly $(p<0.05)$ 
Table 4. The number of Staphylococcus aureus and Escherichia coli in small intestine

\begin{tabular}{llcccc}
\hline \multirow{2}{*}{ Variable } & & \multicolumn{4}{c}{ Groups } \\
\cline { 3 - 6 } & & Control & $\mathbf{1 ~ g / k g}$ & $\mathbf{2} \mathbf{~ g} / \mathbf{k g}$ & $\mathbf{3} \mathbf{~ g} / \mathbf{k g}$ \\
\hline $\begin{array}{l}S . \quad \text { aureus } \\
\left(\mathrm{x} 10^{5}\right)\end{array}$ & $(C F U / g)$ & $1.49^{\mathrm{a}}$ & $1.17^{\mathrm{b}}$ & $1.11^{\mathrm{b}}$ & $1.07^{\mathrm{b}}$ \\
$\begin{array}{l}E \quad \text { coli } \\
\left(\mathrm{x} 10^{5}\right)\end{array}$ & $(C F U / g)$ & $1.47^{\mathrm{a}}$ & $1.15^{\mathrm{b}}$ & $1.00^{\mathrm{c}}$ & $0.96^{\mathrm{c}}$ \\
\hline
\end{tabular}

$\mathrm{a}, \mathrm{b}, \mathrm{c}, \mathrm{d}$ : means within a row with no common superscript differ significantly $(p<0.05)$

Table 4 shows the total number of bacteria observed in small intestine of samples supplemented with different concentration of turmeric powder. It shows that the number of bacteria decreased in line with the increase of turmeric powder addition in the diet. The highest bacteria were observed in the control group. The lowest number of $S$. aureus was obtained in all groups supplemented with different concentration of turmeric powder. While the lowest number of $E$. coli was found in the group with the addition of 2 and $3 \mathrm{~g} / \mathrm{kg}$ turmeric powder, respectively.

\section{Discussion}

The results of present study indicated that turmeric response depends on chicken age and usage dosage. The turmeric powder has no effects on FI, WG and FCR for local chickens aged 1 until 8 weeks, whereas it has significant effect on FI and FCR for chickens aged 9 to 16 weeks. From week 1 to week 8 , Sentul chickens are considered in early young period. Wenk (2003) stated that in the early age, metabolism and nutrient digestion of animals are not yet functioned optimally while in the later age the digestion processes can be optimized and adapted to the available feedstuffs. At the time of hatching, bacterial starts to colonize gastro-intestinal tracts of chickens. However, the bacterial colonialization seems to be stable at older age (Rehman et al. 2007). The composition of the bacterial community in intestinal is influenced by many factors such as diet and age (Lu et al. 2003). As a result, the response of turmeric addition in rations in the present study can be observed in age period of 9 to 16 weeks).

At age of 9-16 weeks, the turmeric powder reduced FI significantly especially in the group with the addition of 2 and $3 \mathrm{~g} / \mathrm{kg}$ turmeric powder, respectively. These results were found to be similar with the results on broiler chickens reported by Ürüşan and Bölükbaş (2017) and local chickens reported by Wang et al. (2015). Ürüşan and Bölükbaş (2017) and Wang et al. (2015) stated that the decrease of FI in their studies may be because of the effects of turmeric aroma on the birds' appetites. Wenk (2003) reported that addition of seven different herbs or herb mixtures in basal diet result in a significant effect on feed intake due to anthraquinone derivatives. Aromatic taste and smell of turmeric are derived from its essential oils (Gupta et al. 2013). Aromatic oily liquids which are extracted by distillation from plant samples such as seeds and flowers are known as essential oils (Adaszyńska-Skwirzyńska and Szczerbińska 2017). In general, dried turmeric rhizomes contain 1.5-5\% essential oils (Gupta et al. 2013). The negative effect of turmeric to feed intake of chickens should be further investigated. This is because the results of studies on feed flavoring and taste research for poultry are still debatable (Damron 2003).

Even though FI reduced significantly in present study, WGs were similar in each treatment. In the present study, supplementation of turmeric powder to rations significantly improved the nutrient digestibility. As a result, it has increased feed digestion and nutrient utilization. These results may indicate some beneficial effects of turmeric powder in intestinal tract as it was found in broiler reported by Al-Sultan (2003), Samarasinghe et al. (2003), Durrani et al. (2006), and Ürüşan \& Bölükbaş (2017) as well as in local chickens reported by Wang et al. (2015). These previous studies stated similar argumentation that turmeric may stimulate protein synthesis particularly increased the secretion of digestive juices and improved the gastrointestinal condition. The improvement of bird performance by dietary supplementation of turmeric, may be due to mechanisms which were proposed by Platel and Shrinivasan (1996; 2004).

Platel and Shrinivasan (1996) reported that curcumin promote pancreatic digestive enzymes of rats such as amylase, lipase, and proteases. Curcumin supplementation also stimulates the liver to secrete more bile enriched in bile acids (Platel and Srinivasan 2004). Liver and pancreas are the main secretive organs in poultry digestive system (Dibner and Richards 2004). The avian liver provides exocrine secretions called bile to emulsify fats and raise the $\mathrm{pH}$ of the duodenal digest, while pancreas provides digestive enzymes and electrolytes, as well as endocrine secretions, consist of insulin and glucagon. The electrolytes resulted from pancreas is important in reducing the acidity of the chime. Higher $\mathrm{pH}$ in intestinal is required for the activity of the digestive enzymes produced by pancreas (Dibner and Richards 2004). Digestive enzymes produced by pancreas break down different types of nutrient. Amylase acts on starch, while lipase breakdown fats. Proteases are essential in protein digestion; however, they also have role in solubilization of fiber (Romero 2014).

The present study showed that the supplementation of turmeric improved FCR of local chickens at aged more than 8 weeks. In particular, supplementation of $3 \mathrm{~g} / \mathrm{kg}$ turmeric powder to diet significantly produced optimum FCR. This result was mainly due to the decreased trend of FI was in line with the increase of turmeric powder in rations while BW was similar among treatments. FCR improvements were found in some studies such as AlSultan (2003), Samarasinghe et al. (2003), Durrani et al. (2006), Wang et al. (2015) and Ürüşan and Bölükbaş (2017). The low FCR in birds fed diets supplemented with turmeric powder indicates the impact of phytogenic products of turmeric that influence nutrient efficiency. Optimization of pancreatic, as well as liver secretions due to turmeric supplementation, may reduce time passage and viscosity of diets. Acceleration of digestive process as a result of increased availability of digestive enzymes and bile acids causes the time reduction of feed transit. Nutrient 
absorption in the small intestine is more optimal in this situation (Platel and Shrinivasan 2004).

The increased availability of digestive secretions may also reduce viscosity of diets in gastrointestinal of chicken. For example, increased proteases in intestinal are able to optimize disruption of proteins with starch and fiber in the diets. Diet with high fiber increases viscosity of feed. The digestion rate would be expected to decrease, as intestinal viscosity increases. In this situation, chicken would perceive a lower nutrient density diet (Bedford 1995). In addition to previous mechanism, Rajput et al. (2013) stated that improved feed efficiency in chicken supplemented with turmeric powder might be due to the larger villus area, which resulted in the improvement of nutrients absorption. The villi are long folds of epithelial cells which is important for enzyme secretion and nutrient absorption (Dibner and Richards 2004).

The $S$. aureus and E. coli amount were less in the groups where the dosage of turmeric powder was increased in the ration. The dose level of 2 and $3 \mathrm{~g} / \mathrm{kg}$ turmeric powder groups added in chicken diets resulted in the lowest number of bacteria. The finding is in agreement with the findings of Samarasinghe et al. (2003) and Lawhavinit et al. (2010). Samaringhe et al. (2003) reported that dietary turmeric powder reduced $E$. coli bacteria in duodenum of the broilers, while Lawhavinit et al. (2010) stated that turmeric could inhibit $S$. aureus of shrimp and chicken. The lower number of bacteria in chickens fed with diet supplemented with turmeric powder may be because of direct and indirect mechanism. Indirect mechanism is that turmeric supplementation may increase digestive secretions. The diet of chickens, as well as interaction between bacteria and intestinal secretions such as mucin and bile acids, influence the bacterial community in the gastrointestinal tract (Rehman et al. 2007). Bedford (1995) argued that the ingested feed can significantly influence the intestinal bacterial populations by increasing viscosity. Increasing viscosity is known to reduce mixing feed and passage rate by which luminal oxygenation may decrease and the bacterial reproduction may increase. The activity of bacteria may reduce the function of bile acids in emulsifying fat resulted in the growth of depression of chickens (Rahman et al. 2007). The present study showed that antimicrobial effect of turmeric increasing nutrient utilization of local chickens. Based on the previous mechanism, increased digestive juices of pancreatic may result in lower viscosity. The reduced viscosity is essential for advantage of microbiota in the intestine of chickens (Romero 2015).

The direct acts of curcumin to reduce or kills the bacteria have several explanations. Wang et al (2003) stated that FtsZ, a prokaryotic homolog of eukaryotic cytoskeletal protein tubulin, acts importantly in cell division by forming a Z-ring. Natural compounds and chemical agents may inhibit of FtsZ to polymerize cause of cell death (Rai et al. 2008). In addition, Rai et al. (2008) provided evidence suggesting that curcumin inhibits FtsZ assembly which leads to disturbance of the Z-ring formation and inhabitation of bacterial cytokinesis. This mechanism is believed as the main instruments of curcumin to inhibit bacterial cell proliferation (Teow et al. 2016). However, a study reported different mechanism of curcumin as anti-bacterial agent. Tyagi et al. (2015) reported that Curcumin I, a commercial curcumin, inhibits both $S$. aureus and E. coli. mainly by damaging the bacterial membrane integrity. Fluorescent probes namely propidium iodide and calcein are used to examine the bacterial membranes, while membrane leakage upon exposure to curcumin was also evaluated by fluorescence and scanning electron microscopes.

The present study suggests that chicken with diets of turmeric powder utilized feed more efficiently; therefore, resulting in a better feed conversion ratio. In addition, the turmeric powder may decrease the activities of some pathogenic bacteria for a better absorption of nutrients. In particular, the level of $3 \mathrm{~g} / \mathrm{kg}$ turmeric powder was found to be beneficial to local chickens since the chickens improved FCR due to positively affected gut bacteria.

\section{ACKNOWLEDGMENTS}

We would like to thank Universitas Padjadjaran, Bandung, Indonesia through Academic Leadership Grant (ALG) for funding this study.

\section{REFERENCES}

Adaszyńska-Skwirzyńska M, Szczerbińska D. 2017. Use of essential oils in broiler chicken production-a review Ann Anim Sci 17 (2): 317335.

Akbarian A, Golian A, Kermanshahi H, Farhoosh R, Raji AR, De Smet S, Michiels J. 2010. Growth performance and gut health parameters of finishing broilers supplemented with plant extracts and exposed to daily increased temperature. Spanish J Agr Res 11 (1): 109-119.

Al-Sultan SI. 2003. The effect of Curcuma longa (turmeric) on overall performance of broiler chickens. Intl J Poult Sci 2: 351-353.

Asmara IY. 2014. Risk Status of Selected Indigenous Chicken Breeds in Java, Indonesia: Challenges and Opportunities for Conservation. [Dissertation]. Research Institute for the Environment and Livelihoods, Faculty of Engineering, Health, Science and the Environment, Charles Darwin University, Darwin, NT, Australia.

Bachirraho G, Abouni B. 2015. Escherichia coli and Staphylococcus aureus most common source of infection. In: Méndez-Vilas A. (ed.). The Battle Against Microbial Pathogens: Basic Science, Technological Advances and Educational Programs. Formatex Research Center, Badajoz, Spain.

Blanco JE. Blanco M, Mora A, Blanco J. 1997. Prevalence of bacterial resistance to quinolones and other antimicrobials among avian Escherichia coli strains isolated from septicemic and healthy chickens. Spain J Clinic Microbiol 35 (8): 2184-2185.

Damron BL. 2003. Feed flavoring for poultry, fact sheet, University of Florida Cooperative Extension Service, Institute of Food and Agriculture Sciences, EDIS, Gainesville, FL. http: //ufdc.ufl.edu/IR00001652/00001

Dibner JJ, Richards JD. 2004. The digestive system: challenges and opportunities. J App Poultry Res 13 (1): 86-93.

Diwyanto K, Iskandar S. 1999. Kampong chickens: a key part of Indonesia's livestock sector. In: Livestock Industries of Indonesia Prior to the Asian Financial Crisis. FAO, Rome, Italy.

Durrani FR, Ismail M, Asad Sultan A, Suhail SM, Chand N, Durrani Z. 2006. Effect of different levels of feed added turmeric (Curcuma longa) on the performance of broiler chicks. J Agr Biol Sci 1 (2): 911.

Ganpati KS, Bhaurao SS, Iranna KK, Dilip CR, Nilkanth YP. 2011. Comparative studies on curcumin content in fresh and stored samples of turmeric rhizomes. Intl Res J Pharma 2 (4): 127-129. 
Gupta SC, Sung B, Kim JH, Prasad S, Li S, Aggarwal BB. 2013. Multitargeting by turmeric, the golden spice: From kitchen to clinic, Mol Nutr Food Res 57: 1510-1528.

Moghadamtousi SZ, Kadir HA, Hassandarvish P, Tajik H, Abubakar S, Zandi K. 2014. A review on antibacterial, antiviral and antifungal activity of curcumin. BioMed Res Intl 2014: 186864. DOI: $10.1155 / 2014 / 186864$.

Nataamijaya AG. 2000. The native chicken of Indonesia. Bull Plasma Nutfah 6: 1-6. [Indonesian]

Nova TD, Yellita Y. 2015. Effect of turmeric powder (Curcuma domestica Val) in feed, on the blood of local duck. J Chem Pharm Res 7 (9S): 215-221.

Lawhavinit O, Kongkathip N, Kongkathip B. 2010. Antimicrobial activity of curcuminoids from Curcuma longa L. on pathogenic bacteria of shrimp and chicken. Kasetsart J Nat Sci 44: 364-371.

Lee SH, Lillehoj HS, Jang SI, Kim DK, Ionescu C, Bravo D. 2010. Effect of dietary Curcuma, Capsicum and Lentinus in enhancing local immunity of against Eimeria acervulina infection. J Poult Sci 47: 8995.

Lu J, Idris U, Harmon B, Hofacre C, Maurer JJ, Lee MD. 2003. Diversity and succession of the intestinal bacterial community of the maturing broiler chicken. App Eviron Microbiol 69 (11): 6816-6824.

Mamza SA, Sunday A, Mamza, Egwu GO, Mshelia GD. 2010. Antibiotic susceptibility patterns of beta-lactamase-producing Escherichia coli and Staphylococcus aureus isolated from chickens in Maiduguri (Arid zone), Nigeria. Veterinarski Arhiv 80 (2): 283-297

Partasasmita R, Hidayat RA, Erawan TS, Iskandar J. 2016. Local knowledge of Karangwangi Village people's, Cianjur District about variation (race), the keeping activity and conservation of chicken (Gallus gallus domesticus Linnaeus, 1758). Pros Sem Nas Masy Biodiv Indon. Andalas University, Padang, 23 April 2016. [Indonesian]

Platel K, Srinivasan K. 1996. Influence of dietary spices or their active principles on digestive enzymes of small intestinal mucosa in rats. Int J Food Sci Nutr 47: 55-59.

Platel K, Srinivasan K. 2004. Digestive stimulant action of spices: A myth or reality. Indian J Med Res 119: 167-179.

Rai D, Singh JK, Roy N, Panda D. 2008. Curcumin inhibits FtsZ assembly: an attractive mechanism for its antibacterial activity, Biochem J 410: 147-155.

Rajput N, Muhammad N, Yan R, Zhong X, Wang T. 2013. Effect of dietary supplementation of curcumin on growth performance, intestinal morphology and nutrients utilization of broiler chicks. J Poult Sci 50: 44-52.

Rehman H, Vahjen W, Awad WA, Zentek J.2007. Indigenous bacteria and bacterial metabolic products in the gastrointestinal tract of broiler chickens. Archives Anim Nutr 61 (5): 319-335.

Romero L. 2014. The role of feed enzymes in poultry gut health. Afma Matrix Oct 2014: 48-53.
Safitri R, Indrawati I, Rossiana N, Miranti M. 2008. Guidebook of basic microbiology practicum. Laboratory of Microbiology. Department of Biology. Universitas Padjadjaran, Sumedang. [Indonesian]

Samarasinghe K, Wenk C, Silva KFST, Gunasekera JMDM. 2003. Turmeric (Curcuma longa) root powder and mannanoligosaccharides as alternatives to antibiotics in broiler chicken diet. Asian-Aus J Anim Sci 16: 1495-1500.

Sulandari S, Zein MSA, Paryanti S, Sartika T, Astuti M, Widjastuti T, Sujana E, Darana S, Setiawan I, Garnida D. 2007. Local chicken genetic resources. In: Diwyanto K, Prijono SN (eds). The biodiversity of Indonesia's local chicken resources: benefits and potential, LIPI Press, Jakarta. [Indonesian]

Sulandari S, Zein MSA, Sartika T. 2008. Molecular characterization of Indonesian indigenous chicken based on mitochondrial DNA displacement (D)-loop sequences. J Biosci 15 (4): 145-154

Teow SY, Liew K, Ali SY, Khoo ASB, Peh SC. 2016. Antibacterial action of curcumin against Staphylococcus aureus: A brief review J Trop Med 2016: Article ID 2853045. DOI: 10.1155/2016/2853045.

Tyagi P, Singh M, Kumari H, Kumari A, Mukhopadhyay K. 2015. Bactericidal activity of curcumin $\mathrm{I}$ is associated with damaging of bacterial membrane. PLoS One 10 (3): e0121313. DOI: 10.1371/journal.pone.0121313

Universitas Padjadjaran. 2012. Purification of Sentul chickens. Faculty of Animal Husbandry, Universitas Padjadjaran, Sumedang \& BPPTU Jatiwangi, Bandung. [Indonesian]

Ürüșan H, Bölükbaș1 ȘC. 2017. Effects of dietary supplementation levels of turmeric powder (Curcuma longa) on performance, carcass characteristics and gut microflora in broiler chickens. J Anim Plant Sci 27 (3): 732-736

Vidotto MC, Miiller EE, de Freitas JC, Alfieri AA, Guimaraes IG, Santos DS. 1990. Virulence factors of avian Escherichia coli. Avian Dis 34: 531-538.

Wang, Dingfa, Huang H, Zhou L, Li W, Zhou H, Hou G, Liu J, Hu L. 2015. Effects of dietary supplementation with Turmeric rhizome extract on growth performance, carcass characteristics, antioxidant capability, and meat quality of Wenchang broiler chickens. Italian J Anim Sci 14: 3870.

Wang J, Galgoci A, Kodali S, Herath KB, Jayasuriya H, Dorso K, Vicente F, Gonzalez A, Cully D, Bramhill D, Singh S. 2003. Discovery of a small molecule that inhibits cell division by blocking FtsZ, a novel therapeutic target of antibiotics. J Biol Chem 278 (45): 44424-44428.

Wenk C. 2003. Herbs and botanicals as feed additives in monogastric animals. Asian-Aust J Anim Sci 16 (2): 282-289.

Widjastuti T. 1996. Determination of Efficiency of Protein Use, Protein Energy Needs for Growth and Production of Sentul Chicken Eggs on Cage System and Litter System. [Dissertation]. Postgraduate Program, Universitas Padjadjaran, Bandung. [Indonesian] 